\title{
Association of the TNF- $\alpha$, IL-2, and IL-2RB gene variants with susceptibility to psoriasis in a Turkish cohort
}

\author{
ASLIHAN GULEL', HUSEYIN SERHAT INALOZ , AYSE FEYDA NURSAL ${ }^{2}$, TUGCE SEVER ${ }^{l}$, \\ SACIDE PEHLIVAN ${ }^{3}$ \\ ${ }^{1}$ Department of Dermatology, Faculty of Medicine, Gaziantep University, Gaziantep, Turkey \\ ${ }^{2}$ Department of Medical Genetics, Faculty of Medicine, Hitit University, Corum, Turkey \\ ${ }^{3}$ Department of Medical Biology, Istanbul Faculty of Medicine, Istanbul University, Istanbul, Turkey
}

\begin{abstract}
Aim of the study: The aim of this study was to investigate the role $T N F-\alpha, I L-2$, and IL-2RB variants in psoriasis (Ps) and to evaluate the association between these variants and clinical features.

Material and methods: A total of 74 psoriatic patients and 74 healthy individuals were genotyped for these variants by PCR and/or RFLP.

Results: The AA genotype of TNF- $\alpha(-308)$ was significantly more common in the patients $(p=0.013)$. $T N F-\alpha(-238) A A$ genotype was significantly increased in the patients $(p=0.028)$, while the GG genotype was decreased in the patient group, compared to the controls $(p=0.016) . I L-2(-330)$ variant $G G$ and TT genotype was more common in the patients ( $p=0.037, p=0.009$, respectively), while IL-2 (-330) GT genotype was increased in the control subjects $(p=0.001)$. IL-2 (-330) GG genotype frequency was significantly decreased $(p=0.021)$ and the TT genotype frequency was significantly increased among patients with psoriatic arthritis in comparison with Ps patients $(p=0.014)$. IL-2RB TC genotype frequency was significantly decreased and TT genotype frequency was significantly increased in the patients with positive family history of Ps compared to those who had a negative family history ( $p=0.017, p=0.014$, respectively). Also, IL-2RB CC genotype was significantly increased among the patients with late-onset Ps in comparison with the early onset Ps group $(p=0.009)$. The frequency of IL-2 (-330) TT genotype was significantly higher in mild Ps patients than moderate-severe patients $(p=0.043)$.

Conclusions: Our data suggest a potential role of these genes as candidate genes for susceptibility to Ps in a Turkish cohort.
\end{abstract}

Key words: psoriasis, tumour necrosis factor $\alpha$, variant, interleukin 2, IL-2 receptor beta.

(Centr Eur J Immunol 2018; 43 (1): 50-57)

\section{Introduction}

Psoriasis (Ps) (OMIM 177900) is a chronic inflammatory dermatological disease manifested by red scaly and welldemarcated skin lesions developed due to the hyperproliferation of epidermal keratinocytes [1]. This proliferation is mediated by cytokines produced by activated tissue-resident immune cells, an infiltrate of T cells, dendritic cells, and cells of the innate immune system, as well as keratinocytes [2]. Studies on genome-wide association have found variants within or near a number of genes encoding cytokines, cytokine receptors, or elements of their signal transduction pathways, and this finding suggests that these cytokines play a role in the mechanism of pathogenesis of this disease [3].

Tumour necrosis factor-alpha (TNF- $\alpha$ ) (OMIM 191160) and interleukin 2 (IL-2) (OMIM 147680) have an impact on regulation of immune and inflammatory responses. The TNF- $\alpha$ gene is located within the major histocompatibility complex (MHC) region on chromosome 6p21.3, a significantly polymorphic region [4]. Since genetic variations in the promoter region may modulate TNF- $\alpha$ production, variants in the promoter region of the TNF- $\alpha$ gene including -308 (rs1800629), -238 (rs361525), and -857 (rs1799724) in humans have been studied for their potential roles on gene transcription as well as their possible associations with certain inflammatory diseases.

IL-2 was originally described as a T cell growth factor; later it was reported that IL-2 induces $\mathrm{T}$ cell proliferation, survival, and differentiation of effectors (Th1/Th2). On the other hand, the main non-redundant function of IL-2 involves sustaining peripheral $\mathrm{T}$ cell tolerance, and the disorders of

Correspondence: Ayse Feyda Nursal, PhD, Hitit University Corum, Medical Faculty Department of Medical Genetics, 19100 Corum,

Turkey, e-mail: feydanursal@hotmail.com

Submitted: 23.03.2017; Accepted: 27.03.2017 
regulatory $\mathrm{T}$ cells are believed to be the basic cause of autoimmunity in the absence of IL-2. This cytokine can also sensitise previously activated T cells to go through apoptosis or activation-induced cell death, restricting the immune response [5]. Human IL-2 gene is encoded on chromosome $4 q 26$ with well-defined variants, of which one -330 (rs2069762) has been described in the promoter region [6]. The IL-2 (-330) variant is associated with cytokine synthesis levels in vitro, with the TT and GT genotypes being related to low production and the GG genotype being associated with increased production [7]. It has been suggested that the IL-2 (-330) variant plays a role in high susceptibility to several inflammatory diseases and malignant neoplasms.

The IL-2 receptor, which plays a role in T-cell-mediated immune responses, is found in three distinct forms in terms of ability to bind IL-2. IL-2 Receptor B (IL-2RB) is located in the $22 \mathrm{q} 13$ chromosomal region. Its protein product belongs to the IL-2 signalling pathway, which is crucial for $\mathrm{T}$ cell activation [8]. There is a T/C polymorphic site located at the $889^{\text {th }}$ nucleotide of IL-2RB mRNA [9]. Due to the relationship between Ps and immunity, we set out to test the association between TNF- $\alpha(-308,-238$, and -857), IL-2 (-330), and IL-2RB (+114) gene variants and Ps in a Turkish cohort.

\section{Material and methods}

\section{Patient population}

The study population consisted of 74 unrelated patients with Ps (40 males and 34 females; mean age: $42.31 \pm 13.94$ years) and 74 (38 males and 36 females; mean age: 40.84 \pm 13.65 years) unrelated healthy controls. Patients were diagnosed and followed at the Department of Dermatology at Gaziantep University, Gaziantep, Turkey. All subjects were from similar ethnic background and the same geographic area. Clinical diagnoses were made by dermatologists, and all patients had at least two skin lesions. The participants were well informed about the nature of this study and their participation was voluntary. Clinical data including family history, age at onset (early onset: $\leq 40$ years, late onset $>40$ years) were collected. Disease severity was quantified by the Psoriasis Area Severity Index (PASI) [10]. Informed, written consent was obtained from all participants, and the design of the study was approved by the local Ethics Committee (TF.09.25).

\section{Genotyping analysis}

The DNA of the participants was isolated from peripheral blood mononuclear cells using the salting out method [11]. TNF- $\alpha$ (-308, -238, and -857), IL-2 (-330), and IL-2RB $(+114)$ gene variants were genotyped by polymerase chain reaction (PCR) restriction fragment length polymorphism (RFLP) analysis, as described previously $[9,12]$. The primer sequences, restriction enzymes, and laboratory conditions related to these variants are listed in Table 1.

\section{Statistical analysis}

All data were analysed using SPSS software version 14.0 for Windows (SPSS Inc., Chicago, IL, USA). The statistical significance of the differences between the patient and the control groups was estimated by Pearson's $\chi^{2}$ analysis [13]. Odds ratio (OR) and $95 \%$ confidence interval $(\mathrm{CI})$ were also calculated. OR $(95 \% \mathrm{Cl})$ was adjusted for age and sex. The data were analysed for appropriateness between the observed and expected genotypes as well as for Hardy-Weinberg Equilibrium (HWE), as described elsewhere. All analyses were two-tailed, and differences were interpreted as statistically significant when $p<0.05$.

\section{Results}

\section{Clinical and demographical characteristics}

Complete demographical information and clinical parameters for the study population are shown in Table 2 .

Table 1. TNF- $\alpha(-308,-238$, and -857), IL-2 (-330), and IL-2RB (+114) primer sequences, restriction enzymes, and conditions

\begin{tabular}{|c|c|c|c|}
\hline Gene regions & Primer sequences & Annealing - cycles & $\begin{array}{l}\text { Restriction enzymes } \\
\text { and conditions }\end{array}$ \\
\hline TNF- $\alpha(-308)$ & $\begin{array}{l}\text { 5'-GAGGCAATAGGTTTTGAGGGCCAT-3' } \\
\text { 5'-GGGACACACAAGCATCAAG-3' }\end{array}$ & $\begin{array}{l}56.3^{\circ} \mathrm{C} \text { versus } \\
30 \text { cycles }\end{array}$ & NcoI, $37^{\circ} \mathrm{C}$ versus $\mathrm{ON}$ inc. \\
\hline TNF- $\alpha(-238)$ & $\begin{array}{c}\text { 5'-AAACAGACCACAGACCTGGTC-3' } \\
\text { 5'-CTCACACTCCCCATCCTCCCGGAT-3' }\end{array}$ & $\begin{array}{l}63.4^{\circ} \mathrm{C} \text { versus } \\
30 \text { cycles }\end{array}$ & MspI, $37^{\circ} \mathrm{C}$ versus $\mathrm{ON}$ inc. \\
\hline $\mathrm{TNF}-\alpha(-857)$ & $\begin{array}{c}\text { 5'-AAGTCGAGTATGGGGACCCCCCGTTAA-3' } \\
\text { 5'-CCCCAGTGTGTGGCCATATCTTCT T-3' }\end{array}$ & $\begin{array}{l}65.8^{\circ} \mathrm{C} \text { versus } \\
30 \text { cycles }\end{array}$ & HincII, $37^{\circ} \mathrm{C}$ versus $\mathrm{ON}$ inc. \\
\hline IL-2 (-330) & $\begin{array}{l}\text { 5'-GGGAAGCACTTAATTATCA-3' } \\
\text { 5'-TAACCTCAАСТCСТGCCACA-3' }\end{array}$ & $\begin{array}{l}57^{\circ} \mathrm{C} \text { versus } \\
32 \text { cycles }\end{array}$ & MwoI, $37^{\circ} \mathrm{C}$ versus $\mathrm{ON}$ inc. \\
\hline IL-2RB (+114) & $\begin{array}{l}\text { 5'-AAGGACACCATTCCGTGGCT-3' } \\
\text { 5'-CCGGTGTTCCTGCAGTTGAT-3' }\end{array}$ & $\begin{array}{l}58^{\circ} \mathrm{C} \text { versus } \\
31 \text { cycles }\end{array}$ & HaeIII, $37^{\circ} \mathrm{C}$ versus $\mathrm{ON}$ inc. \\
\hline
\end{tabular}


Table 2. Demographic and clinical characteristics of patients

\begin{tabular}{ll}
\hline Parameter & $\boldsymbol{n}(\boldsymbol{\%})$ \\
\hline Gender & $34(45.9)$ \\
\hline Female & $40(54.1)$ \\
\hline Male & $42.31 \pm 13.94$ \\
\hline Mean age (years) & $37(50)$ \\
\hline PASI & $37(50)$ \\
\hline Mild (PASI $\leq 10)$ & $49(66.2)$ \\
\hline Moderate-high (PASI $>10)$ & $25(33.8)$ \\
\hline Typease onset $(<40$ y.o.) & $23(31.1)$ \\
\hline Type II $(\geq 40$ y.o.) & $51(68.9)$ \\
\hline Psoriatic arthritis & $34(45.9)$ \\
\hline Yes & $40(54.1)$ \\
\hline No
\end{tabular}

A total of 148 subjects from the Turkish population were recruited in this study. There were $40(54.1 \%)$ males and 34 (45.9\%) females in the patient group. Demographic features such as gender, age, PASI, disease onset, arthritis, and family history of Ps were analysed. The genotype distribution of TNF- $\alpha$ (-308, -238, and-857), IL-2 (-330), and IL-2RB $(+114)$ variants in patients and the controls, as well as their associations with risk of Ps, are shown in Table 3.

\section{TNF- $\alpha(-308,-238$, and -857)}

Genotype distribution of TNF- $\alpha(-308)$ and (-238) variants was found to be significantly different between the patients and the controls. The AA genotype of TNF- $\alpha(-308)$ was significantly more common in the patients than in the controls ( $p=0.013$, OR $=0.475,95 \%$ CI: 0.400-0.565). TNF- $\alpha(-238)$ AA genotype was significantly higher in the patients ( $p=0.028, \mathrm{OR}=0.479,95 \% \mathrm{CI}$ : 0.403-0.589), while the GG genotype was lower in the patients group, compared to the controls $(p=0.016, \mathrm{OR}=3.306,95 \% \mathrm{CI}$ : 1.295-8.440). The analysis of the genotype distribution for TNF- $\alpha(-857)$ variant did not show a statistically significant difference between the groups. The genotype frequencies of the TNF- $\alpha$ (-857) variants were in HWE in both the patients and the controls ( $p=0.129, p=0.17$, respectively). However, genotype distribution of TNF- $\alpha(-308)$ variant in the controls and TNF- $\alpha(-238)$ in the patients did not conform to $\operatorname{HWE}$ ( $p=0.017, p=0.001$ respectively).

\section{IL-2 (-330) and IL-2RB (+114)}

The genotype distribution of the IL-2 (-330) variant was statistically different between the patients and the controls. IL-2 (-330) variant GG and TT genotype was more common in the patients $(p=0.037, \mathrm{OR}=2.716,95 \%$ CI: $1.061-6.949 ; p=0.009, \mathrm{OR}=3.257,95 \%$ CI: $1.387-$ 7.646, respectively), while IL-2 (-330) GT genotype was increased in control subjects $(p=0.001, \mathrm{OR}=5.130,95 \%$ CI: 1.926-3.667). There was no significant difference for the IL-2RB (+114) genotype distribution between the patients and healthy controls. Statistical calculation for IL2RB (+114) indicated that the patient and the control groups were not in HWE, $(p=0.029, p=0.0000$, respectively).

Table 3. Genotype distributions of TNF- $\alpha$, IL-2RB, and IL-2 variants in patients and controls

\begin{tabular}{|c|c|c|c|c|c|c|}
\hline & Genotype & $\begin{array}{c}\text { Patients } \\
n=74(\%)\end{array}$ & $\begin{array}{c}\text { Controls } \\
n=74(\%)\end{array}$ & OR & $95 \% \mathrm{CI}$ & $p$ \\
\hline \multirow[t]{3}{*}{ TNF- $\alpha(-308)$} & AA & $7(9.5)$ & $0(0)$ & $0.475 * *$ & $0.400-0.565^{* *}$ & $0.013 * *$ \\
\hline & $\mathrm{AG}$ & $22(29.7)$ & $32(43.3)$ & $1.502 *$ & $0.752-3.001 *$ & $0.249 *$ \\
\hline & GG & $45(60.8)$ & $42(56.7)$ & $0.864 * *$ & $0.439-1.629 * *$ & $0.739 * *$ \\
\hline \multirow[t]{3}{*}{ TNF- $\alpha(-238)$} & AA & $6(8.1)$ & $0(0)$ & $0.479 * *$ & $0.403-0.589 * *$ & $0.028 * *$ \\
\hline & $\mathrm{AG}$ & $13(17.6)$ & $7(9.5)$ & $0.440^{*}$ & $0.163-1.187 *$ & $0.105 *$ \\
\hline & GG & $55(74.3)$ & $67(90.5)$ & $3.306^{* * *}$ & $1.295-8.440^{* * *}$ & $0.016 * *$ \\
\hline \multirow[t]{3}{*}{ TNF- $\alpha(-857)$} & $\mathrm{CC}$ & $11(14.9)$ & $8(10.8)$ & $0.626^{*}$ & $0.223-1.759^{*}$ & $0.374 *$ \\
\hline & $\mathrm{TC}$ & $27(36.5)$ & $25(33.8)$ & $0.822 *$ & $0.403-1.677^{*}$ & $0.590^{*}$ \\
\hline & $\mathrm{TT}$ & $36(48.6)$ & $41(55.4)$ & $0.763^{* *} *$ & $0.399-1.455^{* *}$ & $0.511^{* *}$ \\
\hline \multirow[t]{3}{*}{ IL-2RB } & $\mathrm{CC}$ & $29(39.2)$ & $43(58.1)$ & $1.805^{*}$ & $0.782-4.167^{*}$ & $0.167 *$ \\
\hline & $\mathrm{TC}$ & $27(36.5)$ & $16(21.6)$ & $0.648^{*}$ & $0.290-1.869^{*}$ & $0.519 *$ \\
\hline & $\mathrm{TT}$ & $18(24.3)$ & $15(20.3)$ & $1.264 * *$ & $0.581-2.749 * *$ & $0.693 * *$ \\
\hline \multirow[t]{3}{*}{ IL-2 (-330) } & GG & $31(41.9)$ & $30(40.5)$ & $2.716^{*}$ & $1.061-6.949 *$ & $0.037 *$ \\
\hline & GT & $20(27)$ & $35(47.3)$ & $5.130 *$ & $1.926-3.667 *$ & $0.001 *$ \\
\hline & TT & $23(31.1)$ & $9(12.2)$ & $3.257 * *$ & $1.387-7.646^{* *}$ & $0.009 * *$ \\
\hline
\end{tabular}

*OR $(95 \%$ CI) corrected age and gender, **Fisher test

Results that are statistically significant are shown in boldface 
Table 4. Genotype distribution of gene variants according to arthritis in patients

\begin{tabular}{lcccccc}
\hline & Genotype & $\begin{array}{c}\text { Arthritis (+) } \\
\boldsymbol{n}=\mathbf{2 3}(\mathbf{\%})\end{array}$ & $\begin{array}{c}\text { Arthritis (-) } \\
\boldsymbol{n}=\mathbf{5 1}(\mathbf{\%})\end{array}$ & OR & $\mathbf{9 5 \%}$ CI & $\boldsymbol{p}$ \\
\hline TNF- $\alpha(-308)$ & AA & $3(13)$ & $4(7.8)$ & $0.643^{*}$ & $0.113-3.576^{*}$ & $0.620^{*}$ \\
& AG & $9(39.1)$ & $13(25.5)$ & $0.386^{*}$ & $0.118-1.261^{*}$ & $0.115^{*}$ \\
& GG & $11(47.9)$ & $34(66.7)$ & $0.458^{* *}$ & $0.168-1.251^{* *}$ & $0.198^{* *}$ \\
\hline TNF- $\alpha(-238)$ & AA & $0(0)$ & $6(11.7)$ & $0.882^{* *}$ & $0.798-0.975^{* *}$ & $0.168^{* *}$ \\
& AG & $4(17.4)$ & $9(17.6)$ & $1.152^{*}$ & $0.287-4.624^{*}$ & $0.842^{*}$ \\
& GG & $19(82.6)$ & $36(70.7)$ & $0.505^{* *}$ & $0.147-1.737^{* *}$ & $0.391^{* *}$ \\
\hline TNF- $\alpha(-857)$ & CC & $5(21.7)$ & $6(11.8)$ & $0.599^{*}$ & $0.132-2.712^{*}$ & $0.506^{*}$ \\
& TC & $4(17.4)$ & $23(45.1)$ & $3.343^{*}$ & $0.903-12.379^{*}$ & $0.071^{*}$ \\
& TT & $14(60.9)$ & $22(43.1)$ & $2.051^{* *}$ & $0.751-5.597 * *$ & $0.211^{* *}$ \\
\hline IL-2RB & CC & $9(39.1)$ & $20(39.2)$ & $0.908^{*}$ & $0.237-3.474^{*}$ & $0.888^{*}$ \\
& TC & $8(34.8)$ & $19(37.3)$ & $0.946^{*}$ & $0.242-3.710^{*}$ & $0.936^{*}$ \\
& TT & $6(26.1)$ & $12(23.5)$ & $1.147^{* *}$ & $0.369-3.563^{* *}$ & $1.000^{* *}$ \\
\hline IL-2 (-330) & GG & $6(26.1)$ & $25(49)$ & $4.491^{*}$ & $1.257-16.047^{*}$ & $\mathbf{0 . 0 2 1 *}$ \\
& GT & $5(21.7)$ & $15(29.4)$ & $2.524^{*}$ & $0.650-9.800^{*}$ & $0.181^{*}$ \\
& TT & $12(52.2)$ & $11(21.6)$ & $3.967^{* *}$ & $1.380-11.401^{* *}$ & $\mathbf{0 . 0 1 4 * *}$ \\
\hline
\end{tabular}

*OR $(95 \%$ CI) corrected age and gender, **Fisher test

Results that are statistically significant are shown in boldface

Table 5. Genotype distribution of gene variants according to family history in patients

\begin{tabular}{lcccccc}
\hline & Genotype & $\begin{array}{c}\text { Family history (+) } \\
n=\mathbf{3 4}(\mathbf{\%})\end{array}$ & $\begin{array}{c}\text { Family history (-) } \\
\boldsymbol{n}=\mathbf{4 0}(\mathbf{\%})\end{array}$ & $\mathbf{O R}$ & $\mathbf{9 5 \%}$ CI & $\boldsymbol{p}$ \\
\hline TNF- $\alpha(308)$ & AA & $6(17.6)$ & $1(2.5)$ & $6.970^{*}$ & $0.741-65.565^{*}$ & $0.090^{*}$ \\
& AG & $9(26.5)$ & $13(32.5)$ & $1.067^{*}$ & $0.364-3.121^{*}$ & $0.906^{*}$ \\
& GG & $19(55.9)$ & $26(65)$ & $0.682^{* *}$ & $0.267-1.743^{* *}$ & $0.479^{* *}$ \\
\hline TNF- $\alpha(238)$ & AA & $4(11.8)$ & $2(5)$ & $2.490^{*}$ & $0.414-14.988^{*}$ & $0.319^{*}$ \\
& AG & $5(14.7)$ & $8(20)$ & $0.699^{*}$ & $0.191-2.560^{*}$ & $0.589^{*}$ \\
& GG & $25(73.5)$ & $30(75)$ & $0.926^{* *}$ & $0.326-2.634^{* *}$ & $1.000^{* *}$ \\
\hline TNF- $\alpha(857)$ & CC & $5(14.7)$ & $6(15)$ & $1.093^{*}$ & $0.259-4.606^{*}$ & $0.904^{*}$ \\
& TC & $13(38.2)$ & $14(35)$ & $1.268^{*}$ & $0.442-3.639^{*}$ & $0.659^{*}$ \\
& TT & $16(47.1)$ & $20(50)$ & $0.889^{* *}$ & $0.356-2.220^{* *}$ & $0.820^{* *}$ \\
\hline IL-2RB & CC & $12(35.3)$ & $17(42.5)$ & $0.274^{*}$ & $0.074-1.019^{*}$ & $0.053^{*}$ \\
& TC & $9(26.5)$ & $18(45)$ & $0.192^{*}$ & $0.050-0.740^{*}$ & $\mathbf{0 . 0 1 7 *}$ \\
& TT & $13(38.2)$ & $5(12.5)$ & $0.231^{* *}$ & $0.072-0.740^{* *}$ & $\mathbf{0 . 0 1 4} * *$ \\
\hline IL-2 (-330) & GG & $11(32.3)$ & $20(50)$ & $0.649^{*}$ & $0.205-2.057^{*}$ & $0.463^{*}$ \\
& GT & $12(35.3)$ & $8(20)$ & $2.168^{*}$ & $0.601-7.818^{*}$ & $0.237^{*}$ \\
& TT & $11(32.4)$ & $12(30)$ & $0.896^{* *}$ & $0.334-2.404^{* *}$ & $1.000^{* *}$ \\
\hline
\end{tabular}

*OR $(95 \%$ CI) corrected age and gender, **Fisher test

Results that are statistically significant are shown in boldface

The observed and expected frequencies of the variation for $\operatorname{IL}-2(-330)$ in patients were not in $\operatorname{HWE}(p=0.0001)$.

\section{Clinical findings according to TNF- $\alpha$, IL-2, and IL-2RB genotypes}

In addition, the relationship between the genotype distribution of TNF- $\alpha$, IL-2, and IL-2RB gene variants and clinical features including arthritis, family history, disease onset, and PASI were also investigated in the patient group (Tables 4-7). TNF- $\alpha(-308,-238$, and -857) variant genotype distribution did not show any difference according to clinical features $(p>0.05)$. IL-2 (-330) GG genotype frequency was significantly lower $(p=0.021)$ and the TT genotype frequency was significantly higher $(p=0.014)$ among patients with psoriatic arthritis in comparison with Ps patients. IL-2RB (+114) TC genotype frequency was significantly lower and TT genotype frequency was significantly higher in patients with positive family history of Ps, compared to the patients with negative family history ( $p=0.017, p=0.014$, respectively). Also, IL-2RB $(+114)$ $\mathrm{CC}$ genotype was significantly high among patients with late-onset Ps in comparison to the early onset Ps group $(p=0.009)$. The frequency of IL-2 (-330) TT genotype 
Table 6. Genotype distribution of gene variants according to disease onset in patients

\begin{tabular}{lcccccc}
\hline & Genotype & $\begin{array}{c}\text { Early onset } \\
\text { (Type I) } \\
n=\mathbf{4 9}(\boldsymbol{\%})\end{array}$ & $\begin{array}{c}\text { Late onset } \\
\text { (Type II) } \\
n=\mathbf{2 5}(\boldsymbol{\%})\end{array}$ & OR & $\mathbf{9 5 \%}$ Cl & $\boldsymbol{p}$ \\
\hline TNF- $\alpha(-308)$ & AA & $7(14.3)$ & $0(0)$ & $0.627^{* *}$ & $0.521-0.754^{* *}$ & $0.088^{* *}$ \\
& AG & $12(24.5)$ & $10(40)$ & $0.777^{* *}$ & $0.159-3.804^{* *}$ & $0.755^{* *}$ \\
& GG & $30(61.2)$ & $15(60)$ & $1.053^{* *}$ & $0.393-2.819^{* *}$ & $1.000^{* *}$ \\
\hline TNF- $\alpha(-238)$ & AA & $6(12.2)$ & $0(0)$ & $0.632^{* *}$ & $0.528-0.758^{* *}$ & $0.090^{* *}$ \\
& AG & $10(20.4)$ & $3(12)$ & $3.738^{*}$ & $0.527-26.502^{*}$ & $0.187^{*}$ \\
& GG & $33(67.4)$ & $22(88)$ & $0.281^{* *}$ & $0.073-1.081^{* *}$ & $0.090^{* *}$ \\
\hline TNF- $\alpha(-857)$ & CC & $8(16.3)$ & $3(12)$ & $0.499^{*}$ & $0.042-5.980^{*}$ & $0.583^{*}$ \\
& TC & $16(32.7)$ & $11(44)$ & $0.297^{*}$ & $0.047-1.880^{*}$ & $0.197^{*}$ \\
& TT & $25(51)$ & $11(44)$ & $1.326^{* *}$ & $0.503-3.491^{* *}$ & $0.628^{* *}$ \\
\hline IL-2RB & CC & $16(32.7)$ & $13(52.0)$ & $0.020^{*}$ & $0.001-0.369^{*}$ & $\mathbf{0 . 0 0 9 *}$ \\
& TC & $18(36.7)$ & $9(36.0)$ & $0.125^{*}$ & $0.010-1.556^{*}$ & $0.106^{*}$ \\
\hline IL-2 $(-330)$ & TT & $15(30.6)$ & $3(12.0)$ & $0.309^{* *}$ & $0.080-1.193^{* *}$ & $0.093^{* *}$ \\
& GG & $18(36.8)$ & $13(52.0)$ & $0.309^{*}$ & $0.044-2.153^{*}$ & $0.236^{*}$ \\
& GT & $13(26.5)$ & $7(28.0)$ & $0.672^{* *}$ & $0.095-4.738^{*}$ & $0.690^{*}$ \\
\hline
\end{tabular}

*OR $(95 \%$ CI) corrected age and gender, **Fisher test

Results that are statistically significant are shown in boldface

Table 7. Genotype distribution of gene variants according to PASI in patients

\begin{tabular}{|c|c|c|c|c|c|c|}
\hline & Genotype & $\begin{array}{c}\text { Mild } \\
(\text { PASI } \leq 10) \\
n=37(\%)\end{array}$ & $\begin{array}{c}\text { Moderate-high } \\
(\text { PASI > 10) } \\
n=37(\%)\end{array}$ & OR & $95 \% \mathrm{CI}$ & $p$ \\
\hline \multirow[t]{3}{*}{ TNF- $\alpha(-308)$} & AA & $5(13.5)$ & $2(5.4)$ & $2.352 *$ & $0.388-14.245^{*}$ & $0.352 *$ \\
\hline & $\mathrm{AG}$ & $11(29.7)$ & $11(29.7)$ & $1.301 *$ & $0.450-3.761 *$ & $0.627 *$ \\
\hline & GG & $21(56.8)$ & $24(64.9)$ & $0.711 * *$ & $0.278-1.815^{* *}$ & $0.634 * *$ \\
\hline \multirow[t]{3}{*}{ TNF- $\alpha(-238)$} & AA & $3(8.1)$ & $3(8.1)$ & $0.885^{* *}$ & $0.161-4.869 * *$ & $0.888 * *$ \\
\hline & $\mathrm{AG}$ & $5(13.5)$ & $8(21.6)$ & $0.500 *$ & $0.137-1.821 *$ & $0.293^{*}$ \\
\hline & GG & $29(78.4)$ & $26(70.3)$ & $1.534 * *$ & $0.535-4.398 * *$ & $0.595 * *$ \\
\hline \multirow[t]{3}{*}{ TNF- $\alpha(-857)$} & $\mathrm{CC}$ & $7(21.7)$ & $4(10.8)$ & $2.455^{*}$ & $0.555-10.862 *$ & $0.236^{*}$ \\
\hline & $\mathrm{TC}$ & $14(17.4)$ & $13(35.1)$ & $1.496^{*}$ & $0.520-4.302 *$ & $0.455^{*}$ \\
\hline & TT & $16(60.9)$ & $20(54.1)$ & $0.648^{* *}$ & $0.259-1.620^{* *}$ & $0.486 * *$ \\
\hline \multirow[t]{3}{*}{ IL-2RB } & $\mathrm{CC}$ & $15(40.5)$ & $14(37.8)$ & $1.525^{*}$ & $0.443-5.245^{*}$ & $0.503^{*}$ \\
\hline & $\mathrm{TC}$ & $14(37.8)$ & $13(35.1)$ & $1.537 *$ & $0.439-5.373^{*}$ & $0.501 *$ \\
\hline & $\mathrm{TT}$ & $8(21.7)$ & $10(27.1)$ & $0.745 * *$ & $0.256-2.166^{* *}$ & $0.787 * *$ \\
\hline \multirow[t]{3}{*}{ IL-2 (-330) } & GG & $13(35.1)$ & $18(48.7)$ & $0.324 *$ & $0.100-10.045^{*}$ & $0.059 *$ \\
\hline & GT & $8(21.6)$ & $12(32.4)$ & $0.326^{*}$ & $0.089-1.193^{*}$ & $0.090 *$ \\
\hline & $\mathrm{TT}$ & $16(43.3)$ & $7(18.9)$ & $0.306^{* *}$ & $1.107-0.874 * *$ & $0.043^{* * *}$ \\
\hline
\end{tabular}

*OR $(95 \%$ CI) corrected age and gender, **Fisher test

Results that are statistically significant are shown in boldface

was significantly higher in mild Ps patients than in moderate-severe patients $(p=0.043)$.

\section{Discussion}

Ps is among the most common chronic inflammatory skin diseases, estimated to affect $1-3 \%$ of the general population. The pathogenesis of this disease has not been established clearly. However, it is thought that Ps is a genetic disease related to inflammation, which is mediated and sustained by numerous factors of the immune system.

The skin is an essential lymphoid organ, bearing an effective immunological surveillance system helped by antigen-presenting cells, cytokine-synthesizing keratinocytes, epidermotropic T cells, dermal capillary endothelial cells, lymph nodes, mast cells, tissue macrophages, granulocytes, fibroblasts, and non-Langerhans cells. Communication among these cells is achieved by cytokine secretion, and they respond through stimulation by bacteria, chemi- 
cals, ultraviolet light, and other irritating factors. Ps is regarded as a T-helper-1 (Th1) disease because an increase in Th1 pathway cytokines (interferon- $\gamma$, TNF- $\alpha$, IL-2, and IL-12 has been detected in the Ps plaques) [14]. In present study, we aimed to investigate the association between TNF- $\alpha$ (-308, -238 and -857), IL-2 (-330), and IL-2RB $(+114)$ variants and Ps.

\section{TNF- $\alpha(-308,-238$, and -857) variants}

TNF- $\alpha$ is essential for local T cell proliferation; it is suggested that the development of Ps is mediated by TNF- $\alpha$, and the proliferation of local $\mathrm{T}$ cells depends on its local synthesis [15]. Some studies reported that psoriatic patients have higher serum levels of TNF- $\alpha[4,16]$. The TNF- $\alpha$ gene is highly polymorphic, and in previous studies it was found that sequence variation in the regulatory region of TNF- $\alpha$ gene has been associated with various disorders. Two $G$ versus A transitions in the promoter region at positions (-308) [17] and (-238) [18] have been reported to have an impact on TNF- $\alpha$ expression. The TNF- $\alpha(-308)$ A allele has been found to have greater potential as a transcriptional activator in vitro compared to the common $\mathrm{G}$ allele [19]. Therefore, the A allele frequency has been associated with the risk of autoimmune disorders [17, 20]. However, the reports of influence of TNF- $\alpha$ (-238) on the transcriptional regulation of TNF have been conflicting [21].

There have been many studies to evaluate the possible association with between TNF- $\alpha$ ( -308 and-238) variants and Ps in different populations. Cabaleiro et al. [22] found that the frequency of the TNF- $\alpha$ (-308 and -238) wild type genotype was greater in patients with Ps than in healthy controls in a Spanish population. Similarly, it was observed that TNF- $\alpha$ (-238) wild type genotype (GG) had a higher prevalence in the patients compared to the controls [23]. But Arias et al. [24] reported that the frequency of TNF- $\alpha$ (-238) GG genotype was decreased in patients but that of GA genotype was increased in patients. It was found that TNF- $\alpha-238$ A allele was more common in psoriatic patients $[25,26]$. Also, it was reported that the frequency of TNF- $\alpha$ (-238) A allele was significantly higher in patients with juvenile-onset Ps in a southwestern Chinese population [27]. In meta-analysis, data suggest that TNF- $\alpha(-308)$ variant is associated with decreased risk of Ps, while TNF- $\alpha(-238)$ is associated with increased risk of Ps [28]. Karam et al. [4] showed that TNF- $\alpha$ (-308) G allele is more common in Ps patients than in controls, and they found that TNF- $\alpha$ serum level was higher in patients with TNF- $\alpha$ (-308) AA genotype. However, some studies have reported no association between TNF- $\alpha(-308) /$ $(-238)$ variant and Ps in different populations [29-31].

We found that genotype distribution of TNF- $\alpha(-308$ and -238) variants was significantly different in the patients. The TNF- $\alpha$ (-308) AA genotype and TNF- $\alpha(-238)$ AA genotype carriers showed a significantly increased risk of developing Ps (Table 2). These findings are consistent with previous studies, which reported that TNF- $\alpha(-308)$ A allele was associated with Ps. In the present study, TNF- $\alpha$ (-238) variant GG genotype was less frequent in the patient group compared to the controls. There are few studies evaluating the association between TNF- $\alpha(-857)$ variant and Ps. Gallo et al. found no association between TNF- $\alpha$ (-857) variant and Ps [23]. However, Cabalerio et al. [22] reported that the frequency of TNF- $\alpha(-857)$ mutant genotype was higher in Ps patients. In the present study there was no significant difference for genotype distribution of TNF- $\alpha$ (-857) between the patients and the healthy controls.

Ps has a large spectrum of clinical features. Numerous population studies conducted to assess the possible association between some TNF- $\alpha$ gene variants ( -308 and -238) and psoriatic arthritis (PsA) resulted in controversial conclusions. Some researchers even established a strong association between these TNF- $\alpha$ promoter variants and PsA, recommending that both variants could be used as biomarkers to anticipate the risk of the disease [32-34]. In the present study, genotype distribution of TNF- $\alpha(-308$, -238 and -857 ) variants according to clinical features including arthritis, family history, disease onset, and PASI did not show any statistical difference.

\section{IL-2 (-330) and IL-2RB (+114) variants}

IL-2 plays a role in the chemical activity of T-cell-assisted immune responses, and as a growth factor it facilitates the cytolytic activity of natural killer cells. Mice lacking expression of IL-2, IL-2RA, and IL-2RB show autoimmunity [35]. The association of IL-2 and IL-2RB genes with several autoimmune diseases could imply a common pathogenic mechanism for these diseases. In previous studies it was reported that IL-2 levels were significantly elevated in the serum of psoriatic patients before treatment compared with those of controls [36, 37]. Warren et al. found that the IL-2 gene variant (rs2069778) is associated with early-onset Ps [38]. Kim et al. suggested that high IL-2 production influenced by IL-2 (-330) G allele could result in the Th1/Th2 cytokine balance to lean towards the Th1-type in Korean Ps, particularly late-onset Ps [39]. Also, Zhou et al. [40] showed that IL-2 (-330) GG and TG genotypes increased the risk in Ps patients who belonged to the northern Chinese Han population. Our results exhibit that GG and TT genotypes of IL-2 (-330) are significantly increased in patients with Ps compared with the control group (Table 3). Our data are consistent with those of Kim et al. and Zhou et al. Although it seems conflicting that genotypes which produce both high and low cytokines were found to be more common in the present study, this finding could be associated with the ethnic diversity of the study group.

In this study, the frequency of IL-2 (-330) GT genotype was significantly low in the patients with Ps com- 
pared to the controls. IL-2 (-330) GG genotype frequency was significantly low and that of TT genotype was significantly high, among patients with psoriatic arthritis, compared with Ps patients. The frequency of IL-2 (-330) TT genotype was significantly higher in mild Ps patients than in moderate-severe patients. Furthermore, the frequency of IL-2RB (+114) CC genotype was significantly high among the patients with late-onset Ps compared with the early onset Ps group. IL-2RB (+114) TC genotype frequency was significantly low and TT genotype frequency was significantly high in patients with positive family history of Ps compared with the patients who had a negative family history. Our results clearly showed that IL-2 and IL2RB variants are associated with clinical features in Ps.

\section{Conclusions}

Our data suggest a potential role of TNF- $\alpha$, IL-2RB, and IL-2 as a candidate gene for susceptibility to Ps in a Turkish population. This may have a potential impact on disease counselling and management. Further large and well-designed case-control studies in diverse ethnic groups with more detailed individual information that include well-matched controls concerning the effects of these gene variants are needed.

\section{The authors declare no conflict of interests.}

\section{References}

1. Chomiczewska-Skóra D, Trznadel-Grodzka E, Rotsztejn H (2013): Psoriasis as a disease associated with the immune system disorders. Centr Eur J Immunol 38: 129-133.

2. Chandra A, Ray A, Senapati S, et al. (2015): Genetic and epigenetic basis of psoriasis pathogenesis. Mol Immunol 64: 313-323.

3. Baliwag J, Barnes DH, Johnston A (2015): Cytokines in psoriasis. Cytokine 73: 342-350.

4. Karam RA, Zidan HE, Khater MH (2014): Polymorphisms in the TNF- $\alpha$ and IL-10 gene promoters and risk of psoriasis and correlation with disease severity. Cytokine 66: 101-105.

5. Malek TR, Bayer AL (2004): Tolerance, not immunity, crucially depends on IL-2. Nat Rev Immunol 4: 665-674.

6. Togawa S, Joh T, Itoh M, et al. (2005): Interleukin-2 gene polymorphisms associated with increased risk of gastric atrophy from Helicobacter pylori infection. Helicobacter 10: 172-178.

7. Hoffmann SC, Stanley EM, Darrin Cox E, et al. (2001): Association of cytokine polymorphic inheritance and in vitro cytokine production in anti-CD3/CD28-stimulated peripheral blood lymphocytes. Transplantation 72: 1444-1450.

8. Pál Z, Antal P, Millinghoffer A, et al. (2010): A novel galectin- 1 and interleukin 2 receptor $\beta$ haplotype is associated with autoimmune myasthenia gravis. J Neuroimmunol 229: 107-111.

9. Wu HC, Chang CH, Wan L, et al. (2006): IL-2 gene C/T polymorphism is associated with prostate cancer. J Clin Lab Anal 20: $245-249$.
10. de Rie MA, Goedkoop AY, Bos JD (2004): Overview of psoriasis. Dermatol Ther 17: 341-349.

11. Miller SA, Dykes DD, Polesky HF (1998): A simple salting out procedure for extracting DNA from human nucleated cells. Nucleic Acids Res 16: 1215.

12. Akcali A, Pehlivan S, Pehlivan M, et al. (2010): TNF-alpha promoter polymorphisms in multiple sclerosis: no association with -308 and -238 alleles, but the -857 alleles in associated with the disease in Turkish patients. Int J Immunogenet 37 : 91-95

13. https://ihg.gsf.de/cgi-bin/hw/hwa2.pl.

14. Schlaak JF, Buslau M, Jochum W, et al. (1994): T cells involved in psoriasis vulgaris belong to the Th1 subset. J Invest Dermatol 102: 145-149.

15. Kastelan D, Kastelan M, Massari LP, et al. (2006): Possible association of psoriasis and reduced bone mineral density due to increased TNF-alpha and IL-6 concentrations. Med Hypotheses 67: 1403-1405.

16. Abanmi A, Al Harthi F, Al Agla R, et al. (2005): Serum levels of pro-inflammatory cytokines in psoriasis patients from Saudi Arabia. Int J Dermatol 44: 82-83.

17. Wilson AG, de Vries N, Pociot F, et al. (1993): An allelic polymorphism within the human tumor necrosis factor alpha promoter region is strongly associated with HLA A1, B8, and DR3 alleles. J Exp Med 177: 557-560.

18. D'Alfonso S, Richiardi PM (1994): A polymorphic variation in a putative regulation box of the TNF-A promoter region. Immunogenetics 39: 150-155.

19. Wilson AG, Symons JA, McDowell TL, et al. (1997): Effects of a polymorphism in the human tumor necrosis factor $\alpha$ promoter on transcriptional activation. Proc Natl Acad Sci 94: 3195-3199.

20. Danis VA, Millington M, Hyland V, et al. (1995): Increased frequency of the uncommon allele of a tumour necrosis factor alpha gene polymorphism in rheumatoid arthritis and systemic lupus erythematosus. Dis Markers 12: 127-133.

21. Kaluza W, Reuss E, Grossmann S, et al. (2000): Different transcriptional activity and in vitro TNF-alpha production in psoriasis patients carrying the TNF-alpha 238A promoter polymorphism. J Invest Dermatol 114: 1180-1183.

22. Cabaleiro T, Román M, Gallo E, et al. (2013): Association between psoriasis and polymorphisms in the TNF, IL12B, and IL23R genes in Spanish patients. Eur J Dermatol 23: 640-645.

23. Gallo E, Cabaleiro T, Román M, et al. (2012): Study of genetic polymorphisms in the tumor necrosis factor $\alpha$ promoter region in Spanish patients with psoriasis. Actas Dermosifiliogr 103: 301-307.

24. Arias AI, Giles B, Eiermann TH, et al. (1997): Tumor necrosis factor-alpha gene polymorphism in psoriasis. Exp Clin Immunogenet 14: 118-122.

25. Nedoszytko B, Szczerkowska-Dobosz A, Zabłotna M, et al. (2007): Associations of promoter region polymorphisms in the tumour necrosis factor-alpha gene and early-onset psoriasis vulgaris in a northern Polish population. Br J Dermatol 157: 165-167.

26. Höhler T, Grossmann S, Stradmann-Bellinghausen B, et al. (2002): Differential association of polymorphisms in the TNF $\alpha$ region with psoriatic arthritis but not psoriasis. Ann Rheum Dis 61: 213-218.

27. Long F, Sun C, Deng D, et al. (2004): TNF-238A is associated with juvenile onset psoriasis in patients of Han population in Southwest China. J Dermatol Sci 36: 109-111. 
28. Zhuang L, Ma W, Cai D, et al. (2013): Associations between tumor necrosis factor- $\alpha$ polymorphisms and risk of psoriasis: a meta-analysis. PLoS One 8: e68827.

29. Baran W, Szepietowski JC, Mazur G, et al. (2006): A -308 promoter polymorphism of tumor necrosis factor alpha gene does not associate with the susceptibility to psoriasis vulgaris. No difference either between psoriasis type I and type II patients. Acta Dermatovenerol Alp Pannonica Adriat 15: 113-118.

30. Kim TG, Pyo CW, Hur SS, et al. (2003): Polymorphisms of tumor necrosis factor (TNF) alpha and beta genes in Korean patients with psoriasis. Arch Dermatol Res 295: 8-13.

31. Chang YT, Chou CT, Yu CW, et al. (2007): Cytokine gene polymorphisms in Chinese patients with psoriasis. Br J Dermatol 156: 899-905.

32. Höhler T, Kruger A, Schneider PM, et al. (1997): A TNF- $\alpha$ promoter polymorphism is associated with psoriasis and psoriatic arthritis. J Invest Dermatol 109: 562-565.

33. Hamamoto Y, Tateno H, Ishida T, et al. (2000): Lack of association between promoter polymorphism of the tumor necrosis factor-alpha gene and psoriatic arthritis in Japanese patients. J Invest Dermatol 115: 1162-1164.

34. Nishibu A, Oyama N, Nakamura K, et al. (2002): Lack of association of TNF-238A and -308A in Japanese patients with psoriasis vulgaris, psoriatic arthritis and generalized pustular psoriasis. J Dermatol Sci 29: 181-184.

35. Sadlack B, Löhler J, Schorle H, et al. (1995): Generalized autoimmune disease in interleukin-2-deficient mice is triggered by an uncontrolled activation and proliferation of CD4+ T cells. Eur J Immunol 25: 3053-3059.

36. Roussaki-Schulze AV, Kouskoukis C, Petinaki E, et al. (2005): Evaluation of cytokine serum levels in patients with plaque-type psoriasis. Int J Clin Pharmacol Res 25: 169-173.

37. Roh NK, Han SH, Youn HJ, et al. (2015): Tissue and Serum Inflammatory Cytokine Levels in Korean Psoriasis Patients: a Comparison between Plaque and Guttate Psoriasis. Ann Dermatol 27: 738-743.

38. Warren RB, Smith RL, Flynn E, et al. (2011): A systematic investigation of confirmed autoimmune loci in early-onset psoriasis reveals an association with IL2/IL21. Br J Dermatol 164: 660-664.

39. Kim YK, Pyo CW, Choi HB, et al. (2007): Associations of IL-2 and IL-4 gene polymorphisms with psoriasis in the Korean population. J Dermatol Sci 48: 133-139.

40. Zhou J, Wang L, Wang F, et al. (2015): 4q27 as a psoriasis susceptibility locus in the Northeastern Chinese Han population. Tissue Antigens 85: 15-19. 